\title{
EFFECT OF ADDING LIPIDOL ON THE UTILIZATION OF BROCCOLI BY- PRODUCT IN GROWING RABBIT DIETS
}

\author{
Fatma T.F. Abd El-Ghany; A. R.H. Habeb; Amal M. Hekal and A.M.M. Saidahmed \\ Animal Production Research Institute, Agricultural Research Center, Dokki, Giza, Egypt.
}

(Received 18/1/2017, Accepted 22/3/2017)

\section{SUMMARY}

$\mathrm{T}$ The aim of the present study was to evaluate the effect of the partial replacement of clover hay $(\mathrm{CH})$ by broccoli product with or without lipidol on growth performance of growing New Zealand White (NEW) rabbits. A total of sixty growing NZW rabbits at four weeks of age were randomly divided into six groups (10 rabbits each). Three different levels of broccoli by- product $(0,5$ and $10 \%)$ of the diet were used, each level of broccoli by- product was fed without or with $0.05 \%$ lipidol. The results showed that there were no negative effect on live body weight and live body weight gain due to levels of broccoli by-product regardless of lipidol. Addition of lipidol during the first period (4-9 weeks of age) improved both of live body weight and live body weight gain, while there was no significant difference between the values during the total experimental period (4-14 weeks of age). And the best treatment compared to the control (T1) was T5 (5\% B+L), while there were no significant differences between the other treatment.Supplementation both broccoli byproduct and lipidol significantly $(\mathrm{P} \leq 0.05)$ reduced fed intake but did not effect on feed conversion. There was a positive effect on all digestion coefficients of nutrients and nutritive values due to level $10 \%$ of broccoli byproduct regardless of lipidol treatment. $\mathrm{T} 4(10 \% \mathrm{~B})$ and $\mathrm{T} 6(10 \% \mathrm{~B}+\mathrm{L})$ resulted in maximum values for carcass dressing \%. Both of the lipidol and broccoli by-product decreased EE\% of rabbit meat. Addition of lipidol to the control and the other groups with broccoli showed an increase in length and slight increase in width of intestinal villi with normal epithelial lining and 5\% replacement was the best. Almost all microbial counts decreased significantly $(\mathrm{P} \leq 0.05)$ due to broccoli replacement and lipidol supplementation. The best relative economical efficiency value was $(133 \%)$ for $\mathrm{T} 5(5 \% \mathrm{~B}+\mathrm{L})$. From the results of this experiment it could be concluded that addition of lipidol with replacement up to $10 \%$ of broccoli by-product in rabbit's diet, resulted in better performance, better economic efficiency and there were no adverse effect on physiological responses and carcass quality.

Keywords: Lipidol, Broccoli by-product, growth performance, blood parameters, caecum microorgannisms, nutrients digistibilities, carcass traits, rabbit.

\section{INTRODUCTION}

The feeding is the major input cost in animal production, accounting for $65-70 \%$ of the total rearing cost. Poor nutrition of animals has been identified as the major constrain to animal production across the developing world (FAO, 2000). On the mean time, agricultural by-products (field and food industrials) amount reached around 32 million tons annually (Egyptian Ministry of Agriculture, 2002), more than two third of this amount is left without use annually. Vegetables vines are the cheapest source of essential amino acids, vitamins and minerals. Using Broccoli by-product can help to reduce feeding cost in rabbit ration, and helps to avoid its environmental pollution hazardous. Broccoli is a plant in the cabbage family whose large flower head is used as vegetables. It belongs to the Brassicacease family. It contains a lot of promoting compounds like minerals, vitamins and fiber. Moreno et al.(2006) found that broccoli contains $103 \mathrm{mg} \mathrm{Ca}, 78 \mathrm{mg} \mathrm{P}, 1.1 \mathrm{mg} \mathrm{Fe}, 15 \mathrm{mg} \mathrm{Na}, 38 \mathrm{mg} \mathrm{K}$, thiamin $0.1 \mathrm{mg}$, riboflavin $0.23 \mathrm{IU}$, niacin $0.9 \mathrm{IU}$ and ascorbic acid 113 IU. Lipidol is prepared from the phospholipids found in soya bean lecithin using enzymes, which remove one of fatty acid chain from the lecithin. Once this chain is removed the molecule has very different chemical and biological properties. Several biologically active phospholipids have been formulated in lipidol as a performance enhancer in animal feed. Lipidol has several benefits that it enhances absorption from the gut, improves bioavailability of feed additives, maximizes enzymatic digestion of feed, helps in maximum nutritional value for high density ration, improves feed conversion 
and animal performance and improves immunity and reduces mortality (Apsaspecialities Company, 2012).

Various experimental tests performed with lipidol in broiler chickens in Dankook University, South Korea in 2010 and 2011 showed a linear improvement in weight gain and feed conversion when lipidol was included at 0.5 and $1 \mathrm{~kg} /$ ton of feed.

Therefore, this study aimed to evaluate incorporation of broccoli by- product, as an untraditional feedstuff in growing New Zealand White rabbit diets with or without lipidol supplementation.

\section{MATRIALS AND METHODS}

The present study was carried out at private farm belong to Ismael Radwan Farm, Sahl- Elhosainya, Sharqia Governorate, Egypt. The experimental work lasted for 70 days. Three different levels of broccoli by- product $(0,5$ and $10 \%)$ of the diet. Each level of broccoli by- product was fed without or with lipidol $(0$ and $0.05 \%)$. Accordingly, a total of experimental diets were used 6 treatments (3 levels of broccoli byproduct $x 2$ levels of lipidol). Table (1) showed the chemical analysis of the tested broccoli by-product. Table (2) showed the formulation and chemical analysis of the experimental diets.

Table (1): Chemical composition of broccoli by-product.

\begin{tabular}{lc}
\hline Item & Component \\
\hline DM & 77.0 \\
Component, \% on DM basis & 14.02 \\
CP & 27.56 \\
CF & \\
Cell wall constituents, \% on DM basis & 45.87 \\
NDF & 35.13 \\
ADF & 2.25 \\
ADL & 0.11 \\
AsE & 8.43 \\
NFE & 26.88 \\
Minerals, \% & \\
Ca & 1.03 \\
P & 0.87 \\
DE, Kcal/Kg & 2073.5 \\
Total Glugosinolate & 2.17 \\
\hline
\end{tabular}

\section{Tested materials:}

Broccoli by- product (the residual of the plant after taking of large flower head) was chopped into 3-5 $\mathrm{cm}$ and was strained, and then lipidol was added to treatments with it. Chemical composition of broccoli by- product was determined according to AOAC (2000). Anti-nutritional factor (glucosinolates) was determined according to Saman et al. (2016). Lipidol is a Korean commercial product developed jointly by Apsaspecialities and Pathway Intermediates Companies; prepared to be used as animal feed additive; it contains lysophospholipids (3\%), other lipids (47\%) and calcium silicate (50\%). Lipidol was supplementated at $0.5 \mathrm{Kg} /$ ton of feed $(0.05 \%)$.

\section{Animals:}

A total number of sixty growing New Zealand White (NZW) rabbits at four weeks of age were randomly divided into six experimental groups (10 rabbits in each) with approximately similar initial body weights. Rabbits were assigned, individually. Rabbits were housed in galvanized metal rabbit battery cages $(60 \times 50 \times 40)$ supplied with separated feeders and fed the experimental diet to meet their nutrients requirements during the growing period according to Agriculture Ministry Decree (1996) recommendations. Diets were offered in pellets form ad libtum, and fresh water was available all times 
from automatic nipple drinkers. All animals were kept under the same managements and hygienic conditions. Any health problems or death were recorded.

Table (2): Formulation and chemical analysis of experimental diets.

\begin{tabular}{|c|c|c|c|c|c|c|}
\hline Ingredient & $\begin{array}{c}\mathrm{T} 1 \\
(\mathrm{Control})\end{array}$ & $\begin{array}{c}\mathrm{T} 2 \\
(\text { Control }+\mathrm{L})\end{array}$ & $\begin{array}{c}\mathrm{T} 3 \\
(5 \% \mathrm{~B})\end{array}$ & $\begin{array}{c}\mathrm{T} 4 \\
(10 \% \mathrm{~B})\end{array}$ & $\begin{array}{c}\mathrm{T} 5 \\
(5 \% \mathrm{~B}+\mathrm{L})\end{array}$ & $\begin{array}{c}\mathrm{T} 5 \\
(10 \% \mathrm{~B}+\mathrm{L})\end{array}$ \\
\hline Barley grains & 16 & 16 & 16 & 16 & 16 & 16 \\
\hline Wheat bran & 27.0 & 27.0 & 27.0 & 23.5 & 27.0 & 23.5 \\
\hline Yellow corn & 8 & 8 & 8 & 8 & 8 & 8 \\
\hline $\begin{array}{l}\text { Soybean meal } \\
(44 \%)\end{array}$ & 12.5 & 12.5 & 12.5 & 16 & 12.5 & 16 \\
\hline Clover hay(17\%) & 30 & 30 & 25 & 20 & 25 & 20 \\
\hline $\begin{array}{l}\text { Broccoli by- } \\
\text { product }\end{array}$ & 0 & 0 & 5 & 10 & 5 & 10 \\
\hline Lime stone & 1.35 & 1.35 & 1.35 & 1.35 & 1.35 & 1.35 \\
\hline $\begin{array}{l}\text { Dicalcium } \\
\text { phosphate }\end{array}$ & 1.3 & 1.3 & 1.3 & 1.3 & 1.3 & 1.3 \\
\hline Molawses & 3.0 & 3.0 & 3.0 & 3.0 & 3.0 & 3.0 \\
\hline DL. Methonine & 0.1 & 0.1 & 0.1 & 0.1 & 0.1 & 0.1 \\
\hline Salt & 0.45 & 0.45 & 0.45 & 0.45 & 0.45 & 0.45 \\
\hline *Vit. \& M. mix. & 0.3 & 0.3 & 0.3 & 0.3 & 0.3 & 0.3 \\
\hline \multicolumn{7}{|l|}{ Chemical analysis } \\
\hline $\mathrm{CP} \%$ & 17.07 & 17.07 & 17.12 & 17.13 & 17.12 & 17.13 \\
\hline $\mathrm{CF} \%$ & 13.04 & 13.04 & 13.01 & 12.84 & 13.01 & 12.84 \\
\hline $\mathrm{EE} \%$ & 2.13 & 2.13 & 2.09 & 2.03 & 2.09 & 2.03 \\
\hline NFE\% & 60.27 & 60.27 & 59.53 & 59.43 & 59.53 & 59.43 \\
\hline Ash\% & 7.65 & 7.65 & 8.25 & 8.37 & 8.25 & 8.37 \\
\hline NDF\% & 37.49 & 37.49 & 37.47 & 37.36 & 37.47 & 37.36 \\
\hline $\mathrm{ADF} \%$ & 19.84 & 19.84 & 20.34 & 15.93 & 20.34 & 15.93 \\
\hline $\begin{array}{l}\text { ADL\% } \\
* * \mathrm{DE}, \mathrm{Kcal} / \mathrm{Kg}\end{array}$ & $\begin{array}{l}6.35 \\
2519\end{array}$ & $\begin{array}{r}6.35 \\
2519\end{array}$ & $\begin{array}{c}6.52 \\
2520\end{array}$ & $\begin{array}{l}5.18 \\
2525\end{array}$ & $\begin{array}{c}6.52 \\
2520\end{array}$ & $\begin{array}{l}5.18 \\
2525\end{array}$ \\
\hline $\mathrm{C} / \mathrm{P}$ ratio & 147.57 & 147.57 & 147.20 & 147.40 & 147.20 & 147.40 \\
\hline $\mathrm{Ca}, \%$ & 1.18 & 1.18 & 1.18 & 1.18 & 1.18 & 1.18 \\
\hline $\begin{array}{l}\text { Total } \\
\text { Phosphorus, \% }\end{array}$ & 0.8 & 0.8 & 0.8 & 0.8 & 0.8 & 0.8 \\
\hline \multicolumn{7}{|c|}{ 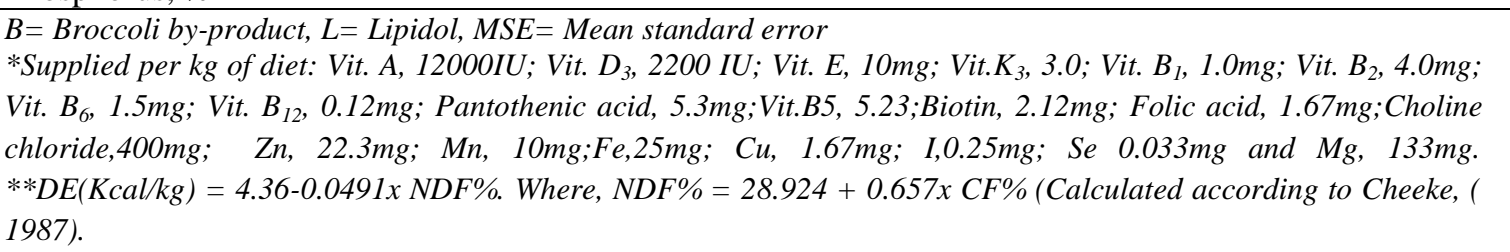 } \\
\hline
\end{tabular}

\section{Growth performance traits:}

Both live body weight and feed intake were recorded weekly, and then body weight gain and feed conversion ratio were calculated.

\section{Digestibility trail:}

At the end of the experimental period (at 14 weeks of age), digestibility trail was carried out using four rabbits of each treatment. Feces were collected daily, weighed and dried at $60-70{ }^{\circ} \mathrm{C}$ for 24 hours, finely ground and stored for chemical analysis. Data of quantities and chemical analysis of feed and feces were used to calculate the nutrients digestion coefficients and the nutritive values of the dietary treatments, as described by Cheeke et al. (1982). Neutral detergent fiber (NDF), acid detergent fiber 
(ADF) and acid detergent lignin (ADL) were determined by method of Van Socest (1982). The samples of feed and feces were chemically analyzed according to AOAC (2000).

Table (3): Effect of the experimental diets on live body and live weight gain.

\begin{tabular}{|c|c|c|c|c|c|c|}
\hline \multirow[t]{2}{*}{ Item } & \multicolumn{3}{|c|}{ Live body weight $(\mathrm{g})$} & \multicolumn{3}{|c|}{ Live body weight gain (g) } \\
\hline & $4 \mathrm{wk}$ & $9 \mathrm{wk}$ & $14 \mathrm{wk}$ & $4-9$ wk & 9-14 wk & 4-14 wk \\
\hline \multicolumn{7}{|c|}{ Effect of Broccoli (B): } \\
\hline $\mathrm{B}(0 \%)$ & 551.65 & $1509.75^{\mathrm{b}}$ & 2536.75 & 958.10 & 1027.00 & 1985.10 \\
\hline $\mathrm{B}(5 \%)$ & 556.05 & $1600.25^{\mathrm{a}}$ & 2636.50 & 1044.20 & 1036.25 & 2080.45 \\
\hline $\mathrm{B}(10 \%)$ & 544.40 & $1516.00^{\mathrm{b}}$ & 2535.25 & 971.60 & 1019.25 & 1990.85 \\
\hline MSE & 8.81 & 61.01 & 41.74 & 61.40 & 51.84 & 42.72 \\
\hline \multicolumn{7}{|c|}{ Effect of lipidol (L): } \\
\hline $\mathrm{L}(0.0 \mathrm{Kg} / \mathrm{Ton})$ & 549.40 & $1505.83^{\mathrm{b}}$ & 2528.00 & $973.63^{\mathrm{b}}$ & 1022.17 & 1977.97 \\
\hline $\mathrm{L}(0.5 \mathrm{Kg} / \mathrm{Ton})$ & 551.37 & $1578.17^{\mathrm{a}}$ & 2611.00 & $1026.80^{\mathrm{a}}$ & 1032.83 & 2059.63 \\
\hline MES & 14.95 & 72.62 & 57.75 & 75.90 & 64.37 & 62.36 \\
\hline \multicolumn{7}{|c|}{ Effect of interaction: } \\
\hline $\mathrm{T} 1$ (Cont.) & 558.80 & 1455.50 & $2533.00^{\mathrm{b}}$ & 896.70 & 1077.50 & $1978.60^{\mathrm{b}}$ \\
\hline $\mathrm{T} 2$ (Cont.+L) & 544.50 & 1564.00 & $2540.50^{\mathrm{b}}$ & 1019.50 & 976.50 & $1996.00^{\mathrm{ab}}$ \\
\hline T3 (B5\%) & 556.90 & 1569.00 & $2576.00^{\mathrm{ab}}$ & 1012.10 & 1007.00 & $2019.10^{\mathrm{ab}}$ \\
\hline $\mathrm{T} 4(\mathrm{~B} 10 \%)$ & 534.40 & 1493.00 & $2475.00^{\mathrm{b}}$ & 958.60 & 982.00 & $1940.60^{\mathrm{b}}$ \\
\hline T5 (B5\%+L) & 555.20 & 1631.50 & $2697.00^{\mathrm{a}}$ & 1076.30 & 1065.50 & $2141.80^{\mathrm{a}}$ \\
\hline T6 (B10\%+L) & 554.40 & 1539.00 & $2595.50^{\mathrm{ab}}$ & 984.60 & 1056.50 & $2041.10^{\mathrm{ab}}$ \\
\hline MSE & 9.53 & 60.65 & 46.15 & 61.73 & 54.71 & 48.68 \\
\hline
\end{tabular}

$a, b \ldots$. Means within each column have no similar letter(s) are significantly different $(P \leq 0.05)$.

$B=$ Broccoli by-product, $L=$ Lipidol, $M S E=$ Mean standard error

\section{Carcass traits:}

At the end of the experimental period (at 14 weeks of age), three rabbits from each group were randomly slaughtered and carcass traits were studied. Relative weight of giblets (heart, liver and kidney) and dressing percentage were calculated according to Steven et al. (1981). Boneless meat of breast and thigh muscle was determined according to AOAC (2000).

\section{Blood parameters:}

Blood samples were collected by vacuum pump into dry clean tubes using heparin as an anticoagulant at 14 weeks of age. The collected samples were centrifuged at $3000 \mathrm{rpm}$ for $15 \mathrm{~min}$, then stored at $-20^{\circ} \mathrm{C}$ for subsequent analysis. Blood plasma was used for determination total protein $(\mathrm{g} / \mathrm{dl})$, albumin $(\mathrm{g} / \mathrm{dl})$, globulin $(\mathrm{g} / \mathrm{dl})$ (was calculated by subtraction of albumin from total protein), $\mathrm{A} / \mathrm{G}$ ratio, alanine aminotransferase (ALT), aspartate aminotransferase (AST), creatinine (mg/dl), glucose (mg/dl) (immediately measured) and cholesterol (mg/dl). All those parameters which were determined calorimetrically using available commercial kits purchased from Diamond Diagnostics Company, Egypt.

\section{Caecum activities and microbial counts:}

Samples of caecum contents from the same slaughtered rabbits from each treatment groups were taken and used immediately for estimation of caecum $\mathrm{pH}$, total volatile fatty acids, ammonia nitrogen concentration and microbiological analysis. The samples of caecum contents were strained through four folds of gauze and divided into two portions, the first portion was used immediately for estimation of PH and ammonia nitrogen concentration. The second portion was preserved by addition of $1 \mathrm{ml} \mathrm{N} / 10 \mathrm{HCL}$ and $2 \mathrm{ml}$ Orthophosphoric acid to each $2 \mathrm{ml}$ of caecum contents juice for determination total volatile fatty acids. The $\mathrm{pH}$ was measured immediately by using a digital $\mathrm{pH}$ meter. The ammonia nitrogen concentration was determined by applying method of Conway (1958). The total volatile fatty acids were determined by steam distillation of the distillate as mentioned by Eadie et al. (1967).

The microbial counts were studied using their selective media, as described by Postage (1969) for Aerobic total bacterial counts and Difco (1989) for Fecal coliforms and E.coli, while, the methods described by Baired Parker (1962) and Kim and Goepfert (1971) were used for Enterococcus count and Bacillus cereus, respectively and Difco (1989) for Enterobacter count, Clostridium sp.; while the method described by Lodder (1952) was used for yeasts determination. Salmonella and Shigella were enumerated according to the methods described by AOAC. (2000). Technique of colony forming unit (CFU) was 
adopted. Incubation took place at $300 \mathrm{C}$ for 2-7 days. The ammonia nitrogen concentration was determined by applying method of Conway (1958). The total volatile fatty acids were determined by steam distillation of the distillate as mentioned by Eadie et al. (1967).

\section{Histopathological examination:}

Small specimens from small intestine of slaughtered animals were collected and fixed in neutral buffered formalin 10\%, dehydrated in alcohol and cleared in xylene then embedded in paraffin. 4-5 mm sections were obtained and stained with Hematoxyline and Eosin (Bancroft et al., 1996).

\section{Statistical analysis:}

Data from all response variables were subjected to a factorial analysis using SAS (2001). Variables having significant differences were compared using Duncan's multiple range test (Steel and Torrie, 1960). The significance level was set at 0.05 ( $\mathrm{p} \leq 0.05)$.

The following model was applied for the statistical analysis;

$\mathrm{Y}_{\mathrm{ijk}}=\mu+\mathrm{B}_{\mathrm{i}}+\mathrm{L}_{\mathrm{j}}+\mathrm{BL}_{\mathrm{ij}}+\mathrm{E}_{\mathrm{ijk}}$;

where;

$\mathrm{Y}_{\mathrm{ijk}}=$ Individual observation .

$\mu=$ Overall mean.

$\mathrm{B}_{\mathrm{i}}=$ Effect of broccoli by-product levels $\left({ }_{i}=1,2\right.$ and 3$)$.

$\mathrm{L}_{\mathrm{j}}=$ Effect of lipidol levels $(\mathrm{j}=1$ and 2$)$.

$\mathrm{BL}_{\mathrm{ij}}=$ Effect of the interaction between broccoli replacement and effect of lipidol.

$\mathrm{E}_{\mathrm{ijk}}=$ Random experimental error.

\section{RESULTS AND DISCUSSION}

\section{Chemical composition of Broccoli by-product:}

Data of Table (1) revealed that broccoli by-product contained a good value of CP (14.02\%), this may be due to good contents of broccoli leaves. Values of CF (27.56\%), NDF (45.87\%) and ADF (35.13\%), this may be due to high contents of the cellulose and hemi cellulose in roots of broccoli by-product. Also, $\mathrm{Ca}$ and $\mathrm{P}$ values were in a good amount (1.03 and $0.87 \%$ respectively). These results were very close to those reported by Ibrahim et al.(2011) who found that broccoli by-product contained 14.26 CP, 23.87 CF, 37.14 NDF, 2.35\% EE. Also, $\mathrm{Ca}$ and $\mathrm{P}$ values were not far from those indicated by $\mathrm{Hu}$ et al. (2011) who found that broccoli by- product contained $1.408 \% \mathrm{Ca}$ and $0.524 \% \mathrm{P}$.

\section{Productive performance:}

\section{Live body and live weight gain:}

Table (3) showed that there was no negative effect on both live body weight and live body weight gain due to levels of broccoli by-product regardless of lipidol. The total live body weight gain values from 414 weeks of age were 1985.1, 2080.45 and $1990.85 \mathrm{~g}$ for 0,5 and $10 \%$ broccoli by-product, respectively, there were no significant differences $(\mathrm{P} \leq 0.05)$ between the previous values. Addition of lipidol during the first period (4-9 weeks of age) improved significantly $(\mathrm{P} \leq 0.05)$ both of live body weight and live body weight gain, while there was no significant difference between the values during the total experimental period (from 4-14 weeks of age). Live body weight gain value was 2059.63 for lipidol vs. $1978.60 \mathrm{~g}$ for the non treated groups. The best value compared to the control (T1) was for T5 $(5 \% \mathrm{~B}+\mathrm{L})$, while there were no significant $(\mathrm{P} \leq 0.05)$ differences between the other treatments. These results agreed with $\mathrm{Hu}$ et al.(2011) who indicated that increasing dietary supplementation $(0,30,60$ and $90 \mathrm{~g} / \mathrm{Kg})$ of dried broccoli stem and leaves meal had no significant effect on production performance of laying hens. Moreover, the study of Apsaspecialities company (2012) that conducted in Sungkyunkwan University (South Korea) of piglets showed that lipidol inclusion at $1 \mathrm{~kg} / \mathrm{ton}$ significantly $(\mathrm{P}<0.05)$ improved weight gain by $12 \%$. 


\section{Feed intake and Feed conversion:}

Table (4) indicated that there was a significant effect on both feed intake and feed conversion due to levels of broccoli by-product regardless of lipidol supplementation. The total feed intake was decreased. The values from 4-14 weeks of age were $5130.85,5129.30$ and $5091.44 \mathrm{~g}$ for 0,5 and $10 \%$ broccoli byproduct, respectively. There were significant differences $(\mathrm{P} \leq 0.05)$ between rabbits fed on $10 \%$ compared with those fed on $0 \%$. There was a significant $(\mathrm{P} \leq 0.05)$ difference between the values of feed conversion ratio during first period (4-9 weeks of age). The values were 2.26, 1.90 and 2.05 for 0,5 and $10 \%$ broccoli by-product, respectively. Addition of lipidol during the second period (from 9-14 weeks of age) and total period (4-14 weeks of age) significantly $(\mathrm{P} \leq 0.05)$ decreased feed intake, while there was no significant improvement for feed conversion during all periods. Feed intake value was $5204.62 \mathrm{~g}$ for the non treated groups vs. $5029.77 \mathrm{~g}$ for lipidol groups during the total period (4-14 weeks). The best feed conversion value compared to the control (T1) recorded with T5 $(5 \% \mathrm{~B}+\mathrm{L})$. These results may be due to the effect of using broccoli by- product as reported by Ibrahim et al. (2011) who noticed performance improving for rabbits fed broccoli by-product related to the beneficial effect on gastrointestinal health. Also, results may be related to the effect of lipidol addition, which has several benefits, it enhances absorption from the gut, improves feed conversion and animal performance and improves immunity and reduces mortality (Apsaspecialities Company, 2012).

Table (4): Effect of the experimental diets on feed intake and feed conversion.

\begin{tabular}{|c|c|c|c|c|c|c|}
\hline \multirow[t]{2}{*}{ Item } & \multicolumn{3}{|c|}{ Feed intake (g/rabbit) } & \multicolumn{3}{|c|}{$\begin{array}{c}\text { Feed conversion ratio } \\
\text { (feed intake, g/weight gain, g) }\end{array}$} \\
\hline & 4-9 wk & 9-14 wk & 4-14 wk & 4-9 wk & $9-14 \mathrm{wk}$ & 4-14 wk \\
\hline \multicolumn{7}{|c|}{ Effect of Broccoli (B): } \\
\hline $\mathrm{B}(0 \%)$ & $1985.05^{\mathrm{a}}$ & 3145.80 & $5130.85^{\mathrm{a}}$ & $2.26^{\mathrm{a}}$ & 3.23 & 2. 61 \\
\hline $\mathrm{B}(5 \%)$ & $1948.80^{b}$ & 3180.50 & $5129.30^{\mathrm{ab}}$ & $1.90^{\mathrm{b}}$ & 3.10 & 2.47 \\
\hline $\mathrm{B}(10 \%)$ & $1942.94^{\mathrm{b}}$ & 3148.50 & $5091.44^{\mathrm{b}}$ & $2.05^{\mathrm{ab}}$ & 3.20 & 2.57 \\
\hline MSE & 29.15 & 35.06 & 59.84 & 0.14 & 0.21 & 0.06 \\
\hline \multicolumn{7}{|c|}{ Effect of lipidol (L): } \\
\hline $\mathrm{L}(0.0 \mathrm{Kg} / \mathrm{Ton})$ & 1954.62 & $3250.00^{\mathrm{a}}$ & $5204.62^{a}$ & 2.13 & 3.27 & 2.64 \\
\hline $\mathrm{L}(0.5 \mathrm{Kg} / \mathrm{Ton})$ & 1963.24 & $3066.53^{b}$ & $5029.77^{\mathrm{b}}$ & 2.01 & 3. 10 & 2. 46 \\
\hline MES & 38.09 & 36.10 & 53.80 & 0.26 & 0.29 & 0.09 \\
\hline \multicolumn{7}{|c|}{ Effect of interaction : } \\
\hline T1(Cont.) & $2070.86^{\mathrm{a}}$ & $3250.00^{\mathrm{a}}$ & $5320.86^{\mathrm{a}}$ & $2.420^{\mathrm{a}}$ & 3.119 & $2.716^{\mathrm{a}}$ \\
\hline $\mathrm{T} 2$ (Cont.+L) & $1899.24^{\mathrm{bc}}$ & $3041.60^{\mathrm{c}}$ & $4940.84^{c}$ & $2.093^{\mathrm{ab}}$ & 3.331 & $2.504^{b c}$ \\
\hline $\mathrm{T} 3(\mathrm{~B} 5 \%)$ & $1891.04^{\mathrm{c}}$ & $3297.00^{\mathrm{a}}$ & $5188.04^{\mathrm{ab}}$ & $1.914^{\mathrm{ab}}$ & 3.296 & $2.578^{\mathrm{ab}}$ \\
\hline $\mathrm{T} 4(\mathrm{~B} 10 \%)$ & $1901.95^{\mathrm{bc}}$ & $3203.00^{\mathrm{ab}}$ & $5104.95^{\mathrm{bc}}$ & $2.055^{\mathrm{ab}}$ & 3.409 & $2.634^{\mathrm{ab}}$ \\
\hline $\mathrm{T} 5(\mathrm{~B} 5 \%+\mathrm{L})$ & $2006.55^{\mathrm{ab}}$ & $3064.00^{\mathrm{c}}$ & $5070.55^{\mathrm{bc}}$ & $1.882^{b}$ & 2.903 & $2.368^{c}$ \\
\hline T6 (B10\%+L) & $1983.93^{a b c}$ & $3094.00^{\mathrm{bc}}$ & $5077.93^{\mathrm{bc}}$ & $2.050^{\mathrm{ab}}$ & 2.998 & $2.504^{b c}$ \\
\hline MSE & 35.73 & 44.07 & 59.07 & 0.17 & 0.22 & 0.07 \\
\hline
\end{tabular}

\section{Digestibility trail:}

Data presented in Table (5) indicated that there was a positive effect on all digestibility coefficients of nutrients and nutritive value for diet contained $10 \%$ broccoli by-product regardless of lipidol treatment. Values were 67.70, 63.80,78.76,57.10,83.24,78.17,70.22 and 13.49 for DM,OM,CP,CF,EE,NFE, TDN and DCP, respectively. There were no significant differences $(\mathrm{P} \leq 0.05)$ between the previous values and control, while there was significantly difference between those values and level of $5 \%$. Addition of lipidol significantly $(\mathrm{P} \leq 0.05)$ improved $\mathrm{DM}$ and $\mathrm{OM}$ digestibility, while, there was no significant difference between the values of $\mathrm{CF}, \mathrm{EE}$ and NFE digestibility, while significantly $(\mathrm{P} \leq 0.05)$ decreased $\mathrm{CP}$ digestibility. Addition of lipidol significantly decreased both TDN and DCP values. These results revealed that $10 \%$ broccoli by-product, improved digestion coefficients of nutrients. The results at that level may be due to the balanced of fiber fraction percentage, NDF (45.87\%) and ADF (35.13\%), soluble fiber has high water holding capacity, readily forms gel, increases luminal viscosity, and is easily 
degraded by micro-flora in the large bowel. On the contrarily, insoluble fiber has little water holding capacity, decreases transit time. These results agreed with Ibrahim et al. (2011) who indicated that the improving in digestion coefficients may be due the large bowel ecosystem in rabbits fed broccoli byproduct and conversely to be protected by fermentable oligosaccharides. The positive effect of lipidol reported by Apsaspecialities Company (2012) was noticed only on digestion coefficients of DM and OM, but the opposite effect was noticed on TDN and DCP. Apsaspecialities Company (2012) reported that lipidol has several benefits; it enhances absorption from the gut, improves bioavailability of feed additives, maximizes enzymatic digestion of feed, and helps in extract of maximum nutritional value from high density ration.

Table (5): Effect of the experimental diets on digestibility coefficients of nutrients (\%) and nutritive values.

\begin{tabular}{|c|c|c|c|c|c|c|c|c|}
\hline \multirow[t]{2}{*}{ Item } & \multirow[t]{2}{*}{$\mathrm{DM}$} & \multirow[t]{2}{*}{$\mathrm{OM}$} & \multirow[t]{2}{*}{$\mathrm{CP}$} & \multirow[t]{2}{*}{$\mathrm{CF}$} & \multirow[t]{2}{*}{$\mathrm{EE}$} & \multirow[t]{2}{*}{ NFE } & \multicolumn{2}{|c|}{ Nutritive values } \\
\hline & & & & & & & TDN & DCP \\
\hline \multicolumn{9}{|c|}{ Effect of Broccoli (B): } \\
\hline $\mathrm{B}(0 \%)$ & $66.77^{\mathrm{ab}}$ & $62.86^{\mathrm{a}}$ & $76.95^{a b}$ & $56.52^{\mathrm{a}}$ & $81.82^{\mathrm{ab}}$ & $78.24^{\mathrm{a}}$ & $70.56^{\mathrm{a}}$ & $13.16^{\mathrm{a}}$ \\
\hline $\mathrm{B}(5 \%)$ & $65.13^{\mathrm{b}}$ & $62.20^{\mathrm{b}}$ & $74.94^{b}$ & $53.03^{\mathrm{b}}$ & $79.89^{b}$ & $76.64^{\mathrm{b}}$ & $67.54^{\mathrm{b}}$ & $12.82^{b}$ \\
\hline $\mathrm{B}(10 \%)$ & $67.70^{\mathrm{a}}$ & $63.80^{\mathrm{a}}$ & $78.76^{\mathrm{a}}$ & $57.10^{\mathrm{a}}$ & $83.24^{\mathrm{a}}$ & $78.17^{\mathrm{a}}$ & $70.22^{\mathrm{a}}$ & $13.49^{\mathrm{a}}$ \\
\hline MSE & 0.48 & 0.63 & 0.49 & 0.91 & 0.42 & 0.40 & 0.48 & 0.08 \\
\hline \multicolumn{9}{|c|}{ Effect of Lipidol (L): } \\
\hline $\mathrm{L}(0.0 \mathrm{Kg} /$ Ton $)$ & $66.40^{\mathrm{b}}$ & $62.79^{b}$ & $79.18^{\mathrm{a}}$ & 56.13 & 82.37 & 78.43 & $70.14^{\mathrm{a}}$ & $13.56^{\mathrm{a}}$ \\
\hline $\mathrm{L}(0.5 \mathrm{Kg} / \mathrm{Ton})$ & $68.81^{\mathrm{a}}$ & $66.67^{\mathrm{a}}$ & $74.58^{\mathrm{b}}$ & 54.97 & 80.93 & 76.94 & $68.74^{\mathrm{b}}$ & $12.74^{\mathrm{b}}$ \\
\hline MES & 0.48 & 0.52 & 0.68 & 0.72 & 0.53 & 0.91 & 0.59 & 0.12 \\
\hline \multicolumn{9}{|c|}{ Effect of interaction } \\
\hline T1 (Cont.) & $64.73^{c}$ & $60.70^{\mathrm{b}}$ & $77.19^{b}$ & $55.13^{b}$ & $81.17^{b}$ & $78.15^{\mathrm{a}}$ & $71.55^{\mathrm{a}}$ & $13.22^{b}$ \\
\hline $\mathrm{T} 2$ (Cont.+L) & $68.81^{a}$ & $65.02^{\mathrm{a}}$ & $76.70^{\mathrm{b}}$ & $57.91^{\mathrm{a}}$ & $82.47^{\mathrm{ab}}$ & $78.33^{\mathrm{a}}$ & $69.57^{\mathrm{bc}}$ & $13.09^{\mathrm{b}}$ \\
\hline T3 (B5\%) & $66.97^{b}$ & $64.22^{\mathrm{a}}$ & $80.10^{\mathrm{a}}$ & $55.24^{b}$ & $82.43^{a b}$ & $77.81^{\mathrm{ab}}$ & $68.09^{\mathrm{cd}}$ & $13.72^{\mathrm{a}}$ \\
\hline $\mathrm{T} 4(\mathrm{~B} 10 \%)$ & $67.49^{\mathrm{ab}}$ & $63.45^{\mathrm{a}}$ & $80.25^{\mathrm{a}}$ & $58.02^{\mathrm{a}}$ & $83.51^{\mathrm{a}}$ & $79.32^{\mathrm{a}}$ & $70.78^{a b}$ & $13.74^{\mathrm{a}}$ \\
\hline $\mathrm{T} 5(\mathrm{~B} 5 \%+\mathrm{L})$ & $63.28^{c}$ & $60.17^{b}$ & $69.78^{c}$ & $50.82^{c}$ & $77.35^{c}$ & $75.46^{b}$ & $66.99^{d}$ & $11.91^{\mathrm{c}}$ \\
\hline T6 (B10\%+L) & $67.91^{\mathrm{ab}}$ & $64.15^{\mathrm{a}}$ & $77.27^{b}$ & $56.17^{\mathrm{ab}}$ & $82.96^{\mathrm{a}}$ & $77.02^{\mathrm{ab}}$ & $69.65^{\mathrm{bc}}$ & $13.23^{b}$ \\
\hline MSE & 0.50 & 0.68 & 0.53 & 0.76 & 0.52 & 0.77 & 0.55 & 0.09 \\
\hline
\end{tabular}

\section{Carcass traits:}

Table (6) showed that there was no negative effect on all carcass traits due to levels of broccoli byproduct regardless of lipidol treatment. Dressing \% values were 52.11, 52.20 and 54.24 for 0, 5 and $10 \%$ broccoli by-product, respectively. There were significant differences $(\mathrm{P} \leq 0.05)$ between rabbits fed on $10 \%$ broccoli and control. Addition of lipidol had significant effect on dressing \% values and intestinal thickness, intestinal thickness was 16.16 for lipidol vs. 16.34 for the non treated groups. While, there was no significant difference between the values of other carcass traits. The best treatment compared to the control (T1) was T4 (10\% B) the dressing \% value for was 54.40 vs. 51.41 for T1 (control). These results may be due to the ability of broccoli in preventing fat disposition (Ibrahim et al., 2011).

Data of Table (7) revealed that EE content of rabbit meat decreased due to levels of broccoli byproduct regardless of lipidol treatment. EE\% values were 1.96, 1.72 and 1.38 for 0,5 and $10 \%$ broccoli by-product, respectively. There were significant differences $(\mathrm{P} \leq 0.05)$ between $10 \%$ and control and between $10 \%$ and $5 \%$, while there were no significant differences between $5 \%$ and control. Addition of lipidol significantly increased CP content and decreased EE content when compared to non treated groups. CP\% and EE\% values were 24.77 and 1.350 for lipidol vs. 23.85 and 2.02 for the non treated groups. While, there was no significant difference between the values of other chemical composition of meat. The best treatment compared to the control (T1) was T6 $(10 \% \mathrm{~B}+\mathrm{L})$, that $\mathrm{CP} \%$ and EE\% values for 
T6 (10\% B+L) were 24.95 and 1.09, respectively vs. 23.84 and 2.29, respectively for T1 (control). The previous results agreed with Apsaspecialities Company (2012) who indicated that lipidol addition contribute to decrease EE\% in meat. Also, these results may be related to the benefits effect of broccoli by-product, broccoli has strong antioxidative properties; lipid oxidation is one of the primary processes of quality deterioration in meat and meat products. Enhanced antioxidant capability in the muscle tends to improve meat quality and extend the shelf life (Tavarez et al., 2011). Impairment of muscle cell membrane integrity could affect the ability of biomembrane to act as a semipermeable barrier and might contribute to exudative loss from meat (Huff-Lonergan and Lonergan, 2005). The volume of drip loss is related to the lipid peroxide contents in the muscle (Juncher et al., 2001 and Tavarez et al., 2011).

Table (6): Effect of the experimental diets on carcass traits and small intestine measurements.

\begin{tabular}{|c|c|c|c|c|c|c|c|c|c|c|c|}
\hline \multirow[t]{2}{*}{ Item } & \multicolumn{8}{|c|}{ Carcass traits } & \multicolumn{3}{|c|}{ Small intestine measurements } \\
\hline & $\begin{array}{c}\text { Carcass } \\
(\%)\end{array}$ & $\begin{array}{c}\text { Liver } \\
(\%)\end{array}$ & $\begin{array}{c}\text { Kidneys } \\
(\%)\end{array}$ & $\begin{array}{c}\text { Heart } \\
(\%)\end{array}$ & $\begin{array}{c}\text { Lungs } \\
(\%)\end{array}$ & $\begin{array}{c}\text { Spleen } \\
(\%)\end{array}$ & $\begin{array}{c}\text { Head } \\
(\%)\end{array}$ & $\begin{array}{c}\text { Dressing } \\
(\%)\end{array}$ & $\begin{array}{c}\text { Impiety } \\
\text { intestinal } \\
\text { weight } \\
(\%)\end{array}$ & $\begin{array}{l}\text { Intestinal } \\
\text { length } \\
\text { (cm) }\end{array}$ & $\begin{array}{c}\text { Intestinal } \\
\text { thickness } \\
(\mathbf{m m})\end{array}$ \\
\hline \multicolumn{12}{|c|}{ Effect of replacement of broccoli $(B)$ : } \\
\hline B $(\mathbf{0 \%})$ & $47.67^{b}$ & 3.34 & 0.77 & 0.35 & 0.70 & 0.05 & 6.03 & $52.11^{b}$ & 1.74 & 234.50 & 17.09 \\
\hline B $(5 \%)$ & $48.44^{\mathrm{ab}}$ & 2.67 & 0.74 & 0.35 & 0.63 & 0.04 & 6.36 & $52.20^{\mathrm{ab}}$ & 1.93 & 262.00 & 16.16 \\
\hline B $(10 \%)$ & $50.05^{\mathrm{a}}$ & 2.98 & 0.81 & 0.39 & 0.64 & 0.05 & 6.54 & $54.24^{\mathrm{a}}$ & 2.35 & 302.00 & 15.51 \\
\hline MSE & 0.73 & 0.40 & 0.06 & 0.05 & 0.09 & 0.01 & 0.30 & 0.53 & 0.23 & 29.69 & 1.26 \\
\hline \multicolumn{12}{|c|}{ Effect of lipidol (L): } \\
\hline L (0.0 Kg/Ton) & 48.68 & 3.05 & 0.74 & 0.36 & 0.63 & 0.04 & 6.31 & 52.82 & 2.03 & 268.22 & $16.34^{\mathrm{a}}$ \\
\hline L (0.5 Kg/Ton) & 48.76 & 2.95 & 0.80 & 0.36 & 0.68 & 0.05 & 6.31 & 52.88 & 1.98 & 264.11 & $16.16^{b}$ \\
\hline MES & 0.39 & 0.24 & 0.06 & 0.04 & 0.06 & 0.01 & 0.07 & 0.54 & 0.21 & 21.11 & 0.43 \\
\hline \multicolumn{12}{|c|}{ Effect of interaction: } \\
\hline T1 (Cont.) & $46.81^{b}$ & 3.53 & 0.75 & 0.33 & $0.67^{\mathrm{b}}$ & 0.04 & 5.82 & $51.41^{\mathrm{c}}$ & $1.64^{b}$ & $219.33^{b}$ & 18.04 \\
\hline T2 (Cont.+L) & $48.52^{a b}$ & 3.16 & 0.78 & 0.36 & $0.73^{\mathrm{a}}$ & 0.05 & 6.24 & $52.81^{\text {abc }}$ & $1.85^{a b}$ & $249.67^{\mathrm{ab}}$ & 16.14 \\
\hline T3 (B5\%) & $48.96^{a b}$ & 2.69 & 0.67 & 0.33 & $0.63^{b}$ & 0.04 & 6.59 & $52.65^{a b c}$ & $2.03^{\mathrm{ab}}$ & $278.00^{a b}$ & 15.11 \\
\hline T4 (B10\%) & $50.26^{\mathrm{a}}$ & 2.92 & 0.81 & 0.41 & $0.60^{b}$ & 0.05 & 6.52 & $54.40^{\mathrm{a}}$ & $2.42^{\mathrm{a}}$ & $307.33^{a}$ & 15.88 \\
\hline T5 (B5\%+L) & $47.92^{a b}$ & 2.65 & 0.81 & 0.36 & $0.63^{b}$ & 0.04 & 6.13 & $51.74^{\text {bc }}$ & $1.83^{\mathrm{ab}}$ & $246.00^{a b}$ & 17.21 \\
\hline T6 $(\mathrm{B} 10 \%+\mathrm{L})$ & $49.84^{\mathrm{a}}$ & 3.05 & 0.82 & 0.37 & $0.67^{b}$ & 0.05 & 6.56 & $54.08^{a b}$ & $2.27^{\mathrm{ab}}$ & $296.67^{a b}$ & 15.13 \\
\hline MSE & 0.89 & 0.35 & 0.05 & 0.04 & 0.07 & 0.01 & 0.24 & 0.75 & 0.21 & 25.28 & 1.03 \\
\hline
\end{tabular}

\section{Histopathology of small intestine:}

Results in Figures (1-6) showed that addition of lipidol to control group and broccoli groups replacement showed increased in length and slight increase in width of intestinal villi with normal epithelial lining and 5\% broccoli was the best one without a wide bad changes. These results might be related to the effect of lipidol. Results agreed with Apsaspecialities Company, (2012) who indicated that the lipidol has several benefits that it enhances absorption from the gut. That, Transverse section through small intestine of rabbit received $10 \%$ broccoli by-product with lipidol showing increase in length and width of intestinal villi with a normal epithelial lining and increase in a number of goblet cells which modified simple columnar epithelial cell whose function is to secrete gel-forming mucins, the major components of mucus. The goblet cells mainly use the merocrine method of secretion, secreting vesicles into a duct, but may use apocrine methods, budding off their secretions, when under stress. Also, the remainder of the cell's cytoplasm is occupied by membrane-bound secretory granules containing mucin which improved intestine health. The goblet shape is due to the mucus laden granules in the apical part expanding, causing that part of the cell to balloon. The apical plasma membrane projects microvilli to give an increased surface area for secretion and absorption (Lohmann-Matthes et al., 1994). 
Table (7): Effect of the experimental diets on chemical composition of carcass meat.

\begin{tabular}{lcccc}
\hline Item & Moisture & CP & EE & Ash \\
\hline Effect of replacement of broccoli (B): & & 24.22 & $1.96^{\mathrm{a}}$ & 1.10 \\
B (0\%) & $72.72^{\mathrm{b}}$ & 24.32 & $1.72^{\mathrm{a}}$ & 1.13 \\
B (5\%) & $72.83^{\mathrm{b}}$ & 24.40 & $1.38^{\mathrm{b}}$ & 1.08 \\
B (10\%) & $73.14^{\mathrm{a}}$ & 0.04 & 0.06 & 0.03 \\
MSE & 0.04 & & & \\
Effect of lipidol (L): & & $23.85^{\mathrm{b}}$ & $2.02^{\mathrm{a}}$ & 1.12 \\
L (0.0 Kg/Ton) & 73.01 & $24.77^{\mathrm{a}}$ & $1.35^{\mathrm{b}}$ & 1.09 \\
L (0.5 Kg/Ton) & 72.79 & 0.03 & 0.06 & 0.03 \\
MES & 0.03 & & & \\
Effect of interaction: & & $23.84^{\mathrm{d}}$ & $2.29^{\mathrm{a}}$ & $1.11^{\mathrm{ab}}$ \\
T1 (Cont.) & $72.76^{\mathrm{cd}}$ & $24.59^{\mathrm{c}}$ & $1.63^{\mathrm{c}}$ & $1.10^{\mathrm{ab}}$ \\
T2 (Cont.+L) & $72.68^{\mathrm{d}}$ & $23.86^{\mathrm{d}}$ & $2.09^{\mathrm{b}}$ & $1.17^{\mathrm{a}}$ \\
T3 (B5\%) & $72.88^{\mathrm{bc}}$ & $23.84^{\mathrm{d}}$ & $1.69^{\mathrm{c}}$ & $1.09^{\mathrm{b}}$ \\
T4 (B10\%) & $73.38^{\mathrm{a}}$ & $24.77^{\mathrm{b}}$ & $1.34^{\mathrm{d}}$ & $1.11^{\mathrm{ab}}$ \\
T5 (B5\%+L) & $72.78^{\mathrm{cd}}$ & $24.95^{\mathrm{a}}$ & $1.09^{\mathrm{e}}$ & $1.06^{\mathrm{b}}$ \\
T6 (B10\%+L) & $72.90^{\mathrm{b}}$ & 0.03 & 0.04 & 0.02 \\
MSE & 0.05 & &
\end{tabular}

$a, b, c, d, e \ldots . .$. Means within each column have no similar letter(s) are significantly different $(P \leq 0.05)$.

$B=$ Broccoli by-product, $L=$ Lipidol, $M S E=$ Mean standard error

\section{Blood constituents:}

From data presented in Table (8) it could be noticed that no negative effect on all blood plasma constituents due to levels of broccoli by-product regardless of lipidol addition. Plasma cholesterol values were $80.30,77.63$ and 82.49 for 0,5 and $10 \%$ broccoli by-product, respectively. There were significant differences $(\mathrm{P} \leq 0.05)$ between level of $5 \%$ and $10 \%$ broccoli only. Addition of lipidol had no significant effect on all plasma constituents values. T3 (5\% B) recorded the highest significantly $(\mathrm{P} \leq 0.05)$ globulin value 2.83 vs. $2.29 \mathrm{~g} / \mathrm{dl}$ for $\mathrm{T} 1$ (control diet). This treatment resulted in $(\mathrm{P} \leq 0.05)$ least cholesterol value.

Table (8): Effect of the experimental diets on plasma parameters.

\begin{tabular}{|c|c|c|c|c|c|c|c|c|c|}
\hline Item & $\begin{array}{c}\text { Total } \\
\text { proteins } \\
\text { (g/dl) }\end{array}$ & $\begin{array}{c}\text { Album } \\
\text { in (A) } \\
(\mathrm{g} / \mathrm{dl})\end{array}$ & 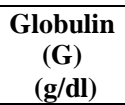 & $\begin{array}{l}\mathbf{A} / \mathbf{G} \\
\text { ratio }\end{array}$ & $\begin{array}{c}\text { Cholestero } \\
\text { l (mg/dl) }\end{array}$ & $\begin{array}{c}\text { Creatinine } \\
(\mathrm{mg} / \mathrm{dl})\end{array}$ & $\begin{array}{c}\text { Glucose } \\
\text { (mg/dl) }\end{array}$ & $\begin{array}{l}\mathbf{A S T} \\
(\mathbf{U} / \mathbf{I})\end{array}$ & $\begin{array}{l}\text { ALT } \\
(\mathbf{U} / \mathbf{I})\end{array}$ \\
\hline \multicolumn{10}{|c|}{ Effect of replacement of broccoli (B): } \\
\hline B $(\mathbf{0 \%})$ & 5.78 & 3.32 & $2.46^{b}$ & $1.36^{\mathrm{a}}$ & 80. $30^{\mathrm{ab}}$ & 0.96 & 190.21 & 32.37 & 23.48 \\
\hline B $(5 \%)$ & 5.90 & 3.26 & $2.65^{\mathrm{a}}$ & $1.27^{\mathrm{b}}$ & $77.63^{b}$ & 0.97 & 189.12 & 33.20 & 23.68 \\
\hline B $(10 \%)$ & 5.72 & 3.39 & $2.47^{b}$ & $1.38^{\mathrm{a}}$ & $82.49^{\mathrm{a}}$ & 0.99 & 189.38 & 33.87 & 22.32 \\
\hline MSE & 0.18 & 0.23 & 0.14 & 0.14 & 3.43 & 0.04 & 6.36 & 1.63 & 1.60 \\
\hline \multicolumn{10}{|c|}{ Effect of lipidol (L): } \\
\hline L (0.0 Kg/Ton) & 5.75 & 3.29 & 2.54 & 1.32 & 80.22 & 0.98 & 189.79 & 33.02 & 23.46 \\
\hline L (0.5 Kg/Ton) & 5.86 & 3.35 & 2.50 & 1.35 & 80.05 & 0.96 & 189.34 & 33.21 & 22.86 \\
\hline MES & 0.19 & 0.19 & 0.07 & 0.10 & 3.92 & 0.03 & 8.81 & 1.78 & 0.91 \\
\hline \multicolumn{10}{|c|}{ Effect of interaction: } \\
\hline T1(Cont.) & 5.64 & 3.35 & $2.29^{b}$ & 1.47 & 83.73 & 0.99 & 187.80 & 32.31 & 23.70 \\
\hline T2 (Cont.+L) & 5.93 & 3.29 & $2.63^{\mathrm{ab}}$ & 1.25 & 76.86 & 0.92 & 192.61 & 32.43 & 23.25 \\
\hline T3 (B5\%) & 6.02 & 3.19 & $2.83^{\mathrm{a}}$ & 1.14 & 74.07 & 0.95 & 189.90 & 33.01 & 23.76 \\
\hline T4 (B10\%) & 5.58 & 3.34 & $2.51^{\mathrm{ab}}$ & 1.34 & 82.87 & 0.99 & 191.67 & 33.73 & 22.91 \\
\hline T5 (B5\%+L) & 5.79 & 3.32 & $2.46^{\mathrm{ab}}$ & 1.39 & 81.18 & 0.98 & 188.33 & 33.18 & 23.60 \\
\hline T6 $(\mathrm{B} 10 \%+\mathrm{L})$ & 5.85 & 3.44 & $2.42^{\mathrm{ab}}$ & 1.42 & 82.11 & 0.98 & 187.08 & 34.01 & 21.72 \\
\hline MSE & 0.15 & 0.18 & 0.15 & 0.13 & 3.83 & 0.04 & 6.03 & 1.67 & 1.30 \\
\hline
\end{tabular}

$a, b \ldots .$. Means within each column have no similar letter(s) are significantly different $(P \leq 0.05)$.

$B=$ Broccoli by-product, $L=$ Lipidol, $M S E=$ Mean standard error 
These results may be related to benefits of broccoli by-product that, it enhanced antioxidant capability in blood constituents and decreased cholesterol (Tavarez et al., 2011). Also, results agreed with Apsaspecialities Company (2012) who reported that a source in diet has important effects in blood parameters in animals. Besides, lysolecitins (as lipidol) increase tocopherol and cholesterol absorption. Moreover, Young Hyun et al., (2016) indicated that There was the quadratic response of glucose level in blood $(\mathrm{P}<0.01)$ with increasing LIPIDOLTM level. Furthermore, the broilers fed diet containing $0.10 \%$ LIPIDOLTM was greater high density lipoprotein than that of in positive control group $(\mathrm{P}<0.05)$.

\section{Caecum activities and microbial counts:}

Data in Tables (9) showed that there was a significant effect on caecum activities due to levels of broccoli by-product regardless of lipidol addition. $\mathrm{pH}$, ammonia and TVFAs values were 6.73, 11.64 $\mathrm{mg} / 100 \mathrm{ml}$ and $3.66 \mathrm{ml} \mathrm{eq} / 100 \mathrm{ml}$, respectively for $0 \%$ broccoli by-product, $7.42,10.66$ and 3.51 respectively for $5 \%$ broccoli by-product, and $7.70,10.35$ and 3.44 respectively for $10 \%$ broccoli byproduct. There were significant differences $(\mathrm{P} \leq 0.05)$ between the previous values. Addition of lipidol increased significantly $(\mathrm{P} \leq 0.05)$ TVFA value. TVFA value was 3.70 for lipidol vs. 3.24 for the control. T2 (Cont. $+\mathrm{L})$ resulted in maximum TVFA value (3.81 vs. 3.51 for T1 control diet), while T6 $(10 \% \mathrm{~B}+\mathrm{L})$ resulted in $(\mathrm{P} \leq 0.05)$ least ammonia value (10.14 vs.11.72). These results agreed with Ibrahim et al.(2011) who indicated that, there was improving in caecum activities attributed to the ability of broccoli in the utilization of low protein diet by conferred some protection in terms of colon morphology.

Table (9): Effect of experimental diets on caecum activities.

\begin{tabular}{|c|c|c|c|}
\hline Item & $\mathrm{pH}$ & Ammonia (mg/100ml) & TVFA (ml eq/100ml) \\
\hline \multicolumn{4}{|c|}{ Effect of replacement of broccoli (B): } \\
\hline $\mathrm{B}(0 \%)$ & $6.73^{\mathrm{c}}$ & $11.64^{\mathrm{a}}$ & $3.66^{\mathrm{a}}$ \\
\hline $\mathrm{B}(5 \%)$ & $7.42^{b}$ & $10.66^{\mathrm{b}}$ & $3.51^{\mathrm{ab}}$ \\
\hline $\mathrm{B}(10 \%)$ & $7.70^{\mathrm{a}}$ & $10.35^{\mathrm{c}}$ & $3.44^{\mathrm{b}}$ \\
\hline MSE & 0.04 & 0.03 & 0.03 \\
\hline \multicolumn{4}{|c|}{ Effect of lipidol (L): } \\
\hline $\mathrm{L}(0.0 \mathrm{Kg} / \mathrm{Ton})$ & 7.65 & 10.56 & $3.24^{\mathrm{b}}$ \\
\hline $\mathrm{L}(0.5 \mathrm{Kg} / \mathrm{Ton})$ & 7.33 & 10.73 & $3.70^{\mathrm{a}}$ \\
\hline MES & 0.04 & 0.03 & 0.03 \\
\hline \multicolumn{4}{|c|}{ Effect of interaction: } \\
\hline T1(Cont.) & $6.67^{c}$ & $11.72^{\mathrm{a}}$ & $3.51^{\mathrm{c}}$ \\
\hline T2 (Cont.+L) & $6.78^{c}$ & $11.55^{\mathrm{b}}$ & $3.81^{\mathrm{a}}$ \\
\hline T3 (B5\%) & $7.38^{b}$ & $10.82^{\mathrm{c}}$ & $3.36^{\mathrm{d}}$ \\
\hline $\mathrm{T} 4(\mathrm{~B} 10 \%)$ & $7.65^{\mathrm{a}}$ & $10.56^{\mathrm{d}}$ & $3.24^{\mathrm{e}}$ \\
\hline T5 (B5\%+L) & $7.46^{b}$ & $10.50^{\mathrm{d}}$ & $3.65^{b}$ \\
\hline T6 (B10\%+L) & $7.74^{\mathrm{a}}$ & $10.14^{\mathrm{e}}$ & $3.64^{b}$ \\
\hline MSE & 0.05 & 0.03 & 0.03 \\
\hline
\end{tabular}

Table (10) revealed a decrease in microbial counts due to levels of broccoli by-product regardless of lipidol addition. That, almost all microbial count significantly $(\mathrm{P} \leq 0.05)$ decreased. Salmonella and Shigella were not detected in all treatments. Aerobic total counts were $8.99 \times 10^{8}, 6.18 \times 10^{8}$ and $6.06 \times 10^{8}$, respectively for 0,5 and $10 \%$ broccoli by-product, respectively. There were significant differences $(\mathrm{P} \leq$ 0.05 ) between levels of $5 \%$ and $10 \%$ broccoli and control. Also, Addition of lipidol decreased significantly $(\mathrm{P} \leq 0.05)$ almost all microbial counts. The best treatment compared to the control (T1) was T6 $(\mathrm{B} 10 \%+\mathrm{L})$ which resulted in $(\mathrm{P} \leq 0.05)$ least values all microbial counts. These results may be related to replacement of broccoli, as reported by Manici et al. (1997) who found that the glucosinolates and some its metabolites have antifungi effect. Glucosinolates occur as secondary metabolites of almost all plants of the order Brassicales. Also, Ibrahim et al. (2011) indicated that, any significant results may be attributed to the medicinal substances or the bioactive compounds (glucosinolates) of broccoli.

\section{Economical efficiency:}

Data presented in Table (11) revealed that economical efficiency was high for using broccoli and addition of lipidol at all levels and T5 recorded (133.41) the best relative economic efficiency followed by 
T6 $125.60 \%$ when compared with the control without lipidol addition. These results may be due to decreasing the prices of diets containing broccoli by-product with and without addition of lipidol, and increasing the weight gain for rabbit fed broccoli by-product with addition of lipidol when compared with control diet. Addition of lipidol improve animal performance as a reported by Apsaspecialities company (2012). These results also, agreed with Ibrahim et al. (2011) who indicated that, high economic effeciency may be attributed to the ability of broccoli in improving the utilization of low protein diet.

Table (10): Effect of the experimental diets on caecum microbial counts $\left(x_{10}^{8} \mathrm{CFU} / \mathrm{ml}\right)$.

\begin{tabular}{|c|c|c|c|c|c|c|c|c|c|}
\hline Item & (1) & (2) & (3) & (4) & (5) & (6) & (7) & (8) & (9) \\
\hline \multicolumn{10}{|c|}{ Effect of replacement of broccoli (B): } \\
\hline $\mathrm{B}(0 \%)$ & $8.99^{\mathrm{a}}$ & $6.10^{\mathrm{a}}$ & $6.79^{\mathrm{a}}$ & 4. $39^{\mathrm{b}}$ & 4. $72^{\mathrm{a}}$ & $1.49^{\mathrm{a}}$ & $3.86^{\mathrm{a}}$ & $5.58^{\mathrm{a}}$ & ND \\
\hline $\mathrm{B}(5 \%)$ & $6.18^{\mathrm{b}}$ & $4.03^{b}$ & $3.77^{\mathrm{b}}$ & $5.65^{\mathrm{a}}$ & $3.68^{b}$ & $1.09^{\mathrm{b}}$ & $4.04^{\mathrm{a}}$ & $4.44^{\mathrm{b}}$ & ND \\
\hline B $(10 \%)$ & $6.06^{\mathrm{b}}$ & $3.97^{\mathrm{b}}$ & $3.56^{\mathrm{b}}$ & $4.26^{\mathrm{c}}$ & $3.23^{c}$ & $1.03^{\mathrm{b}}$ & $3.49^{b}$ & $3.85^{\mathrm{c}}$ & ND \\
\hline MSE & 0.13 & 0.24 & 0.15 & 0.15 & 0.15 & 0.05 & 0.13 & 0.01 & - \\
\hline \multicolumn{10}{|c|}{ Effect of lipidol (L): } \\
\hline $\mathrm{L}(0.0 \mathrm{Kg} /$ Ton $)$ & 7.28 & $5.11^{\mathrm{a}}$ & $5.26^{\mathrm{a}}$ & $5.00^{\mathrm{a}}$ & $4.32^{\mathrm{a}}$ & $1.36^{\mathrm{a}}$ & $4.19^{\mathrm{a}}$ & 4.71 & ND \\
\hline $\mathrm{L}(0.5 \mathrm{Kg} /$ Ton $)$ & 6.87 & $4.30^{\mathrm{b}}$ & $4.16^{\mathrm{b}}$ & $4.53^{b}$ & $3.43^{b}$ & $1.04^{\mathrm{b}}$ & $3.40^{\mathrm{b}}$ & 4.53 & ND \\
\hline MES & 0.20 & 0.29 & 0.16 & 0.16 & 0.19 & 0.05 & 0.15 & 0.15 & - \\
\hline \multicolumn{10}{|c|}{ Effect of interaction: } \\
\hline T1(Cont.) & $9.27^{\mathrm{a}}$ & $6.98^{\mathrm{a}}$ & $7.25^{\mathrm{a}}$ & $4.77^{\mathrm{c}}$ & $5.32^{\mathrm{a}}$ & $1.95^{\mathrm{a}}$ & $4.61^{\mathrm{a}}$ & $5.82^{\mathrm{a}}$ & ND \\
\hline T2 (Cont.+L) & $8.72^{b}$ & $5.22^{b}$ & $6.33^{\mathrm{b}}$ & $4.01^{\mathrm{d}}$ & $4.12^{b}$ & $1.03^{\mathrm{b}}$ & $3.10^{\mathrm{d}}$ & $5.33^{b}$ & ND \\
\hline $\mathrm{T} 3(\mathrm{~B} 5 \%)$ & $6.27^{\mathrm{c}}$ & $4.12^{c}$ & $4.37^{\mathrm{c}}$ & $6.13^{\mathrm{a}}$ & $4.25^{b}$ & $1.11^{\mathrm{b}}$ & $4.22^{b}$ & $4.50^{\mathrm{c}}$ & ND \\
\hline $\mathrm{T} 4(\mathrm{~B} 10 \%)$ & $6.30^{c}$ & $4.23^{c}$ & $4.15^{\mathrm{c}}$ & $4.10^{\mathrm{d}}$ & $3.38^{\mathrm{c}}$ & $1.03^{\mathrm{b}}$ & $3.73^{c}$ & $3.82^{\mathrm{d}}$ & ND \\
\hline $\mathrm{T} 5(\mathrm{~B} 5 \%+\mathrm{L})$ & $6.08^{\mathrm{cd}}$ & $3.95^{\mathrm{c}}$ & $3.18^{\mathrm{d}}$ & $5.17^{\mathrm{b}}$ & $3.11^{\mathrm{c}}$ & $1.08^{\mathrm{b}}$ & $3.85^{\mathrm{c}}$ & $4.38^{c}$ & ND \\
\hline T6 (B10\%+L) & $5.81^{\mathrm{d}}$ & $3.72^{c}$ & $2.97^{\mathrm{d}}$ & $4.42^{\mathrm{cd}}$ & $3.07^{\mathrm{c}}$ & $1.02^{\mathrm{b}}$ & $3.25^{\mathrm{d}}$ & $3.87^{\mathrm{d}}$ & ND \\
\hline MSE & 0.14 & 0.18 & 0.13 & 0.13 & 0.12 & 0.04 & 0.11 & 0.11 & - \\
\hline
\end{tabular}

$(1)=$ Aerobic total count,$(2)=$ Fecal coliforms, $(3)=$ E. Coli, $(4)=$ Bacillus cereus, $(5)=$ Enterobacter, $(6)=$

Clostridium, $(7)=$ Enterococcus, $(8)=$ Yeasts, $(9)=$ Salmonella $\&$ Shigella.

$B=$ Broccoli by-product, $L=$ Lipidol, MSE $=$ Mean standard error

$a, b, c$ and $d . .$. Means within each column have no similar letter(s) are significantly different $(P \leq 0.05)$.

Each value is an average of 3 observations. $N D=$ Not detected.

Number of bacterial cells per gram of caecum content $\left(X 10^{8} \mathrm{CFU} / \mathrm{ml}\right)$. CFU (Colony forming unite).

Table (11): Effect of the experimental diets on economical efficiency of rabbits during the period from 4-14 weeks of age.

\begin{tabular}{|c|c|c|c|c|c|c|}
\hline \multirow[t]{2}{*}{ Item } & \multicolumn{6}{|c|}{ Experimental treatments } \\
\hline & $\begin{array}{c}\mathrm{T} 1 \\
\text { (Cont.) }\end{array}$ & $\begin{array}{c}\mathrm{T} 2 \\
(\text { Cont.+L) }\end{array}$ & $\begin{array}{c}\mathrm{T} 3 \\
(\mathrm{~B} 5 \%)\end{array}$ & $\begin{array}{c}\mathrm{T} 4 \\
(\mathrm{~B} 10 \%)\end{array}$ & $\begin{array}{c}\mathrm{T} 5 \\
(\mathrm{~B} 5 \%+\mathrm{L})\end{array}$ & $\begin{array}{c}\mathrm{T} 6 \\
(\mathrm{~B} 10 \%+\mathrm{L})\end{array}$ \\
\hline Price diet $/ \mathrm{kg} \mathrm{L.E}$ & 3.55 & 3.60 & 3.30 & 3.25 & 3.35 & 3.30 \\
\hline Total feed intake $(\mathrm{g})$ & 5320.86 & 4940.84 & 5188.04 & 5104.95 & 5070.55 & 5077.93 \\
\hline Total weight gain (g) & 1974.20 & 1996.00 & 2019.10 & 1940.60 & 2141.80 & 2041.10 \\
\hline Total feed cost (L.E) & 18.89 & 17.79 & 17.12 & 16.59 & 16.99 & 16.76 \\
\hline Price of $\mathrm{kg}$ rabbit weight & 25 & 25 & 25 & 25 & 25 & 25 \\
\hline Total revenue (L.E) & 49.36 & 49.90 & 50.48 & 48.52 & 53.55 & 51.03 \\
\hline$*$ Net revenue (L.E) & 30.47 & 32.11 & 33.36 & 31.93 & 36.56 & 34.27 \\
\hline$* *$ Economic efficiency & 161.30 & 180.49 & 194.86 & 192.47 & 215.19 & 202.60 \\
\hline $\begin{array}{l}* * * \text { Relative economic } \\
\text { efficiency }(\%)\end{array}$ & 100 & 111.90 & 120.81 & 119.32 & 133.41 & 125.60 \\
\hline
\end{tabular}




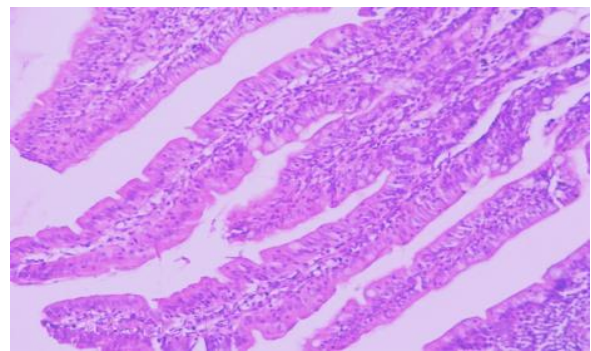

Figure (1): Transverse section through small intestine of rabbit (control group) showing normal histological structure; H\&E (200 X).

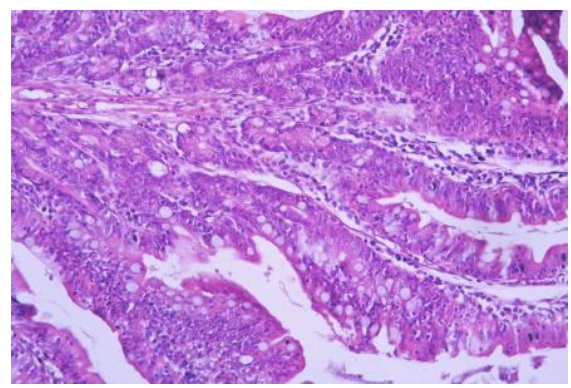

Figure (3): Transverse section through small intestine of rabbit received $5 \%$ broccoli by-product showing normal length and width of intestinal villi with a normal epithelial lining and increase in a number of

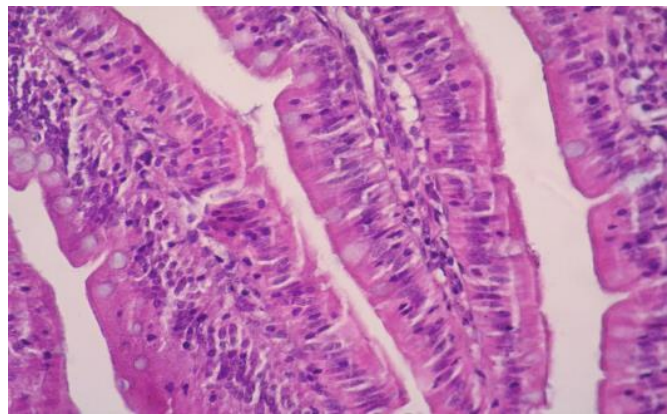

Figure (5): Transverse section through small intestine of rabbit received $5 \%$ broccoli by- product with lipidol showing increase in intestinal length and width with a normal structure of intestinal gland: H\&E (200 X).

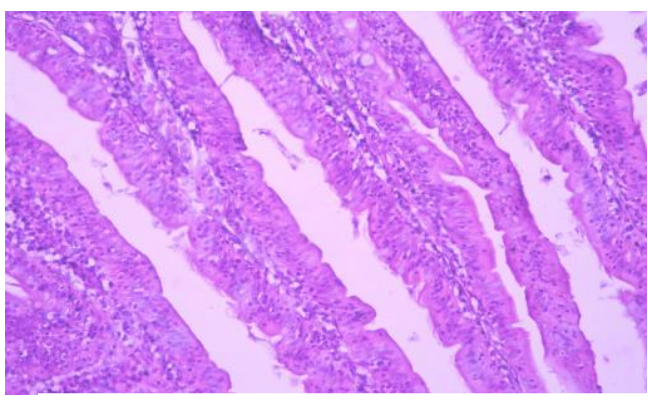

Figure (2): Transverse section through small intestine of rabbit received control diet with lipidol, showing increase in length and slight increase in width of intestinal villi with normal epithelial lining, H\&E $(200 \mathrm{X})$.

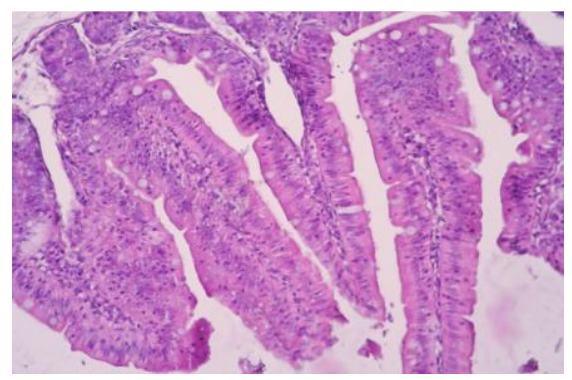

Figure (4): Transverse section through small intestine of rabbit received $10 \%$ broccoli by-product showing slight decrease in length some of them decrease in width with a normal structure of intestinal gland, with inflammatory cells infiltration; $H \& E$ $(\boldsymbol{m o n} \mathrm{V})$

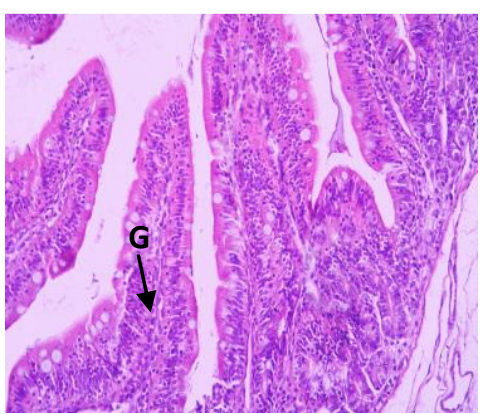

Figure (6): Transverse section through small intestine of rabbit received $10 \%$ broccoli by-product with lipidol showing increase in length and width of intestinal villi with a normal epithelial lining and increase in a number of Goblet cells (G) ; H\&E (200 X). 


\section{CONCLUSION}

It could be concluded from the present study that addition of lipidol with replacement $10 \%$ of broccoli by-product in rabbit's diet, resulted in better performance without any adverse effect on physiological responses and carcass quality.

\section{AKNOWLEDGEMENTS}

The authors thank each of Apsaspecialities \& Pathway Intermediates Companies Team and Prof. Dr. Kamal Y. El-Nagmy, Poultry Feeding Research Department (APRI) for supplying of Lipidol that used in the study and for his support.

\section{REFERENCES}

Agriculture Ministry Decree (1996). The standard properties for ingredients, feed additives and feed manufactured for animal and poultry. El-Wakaee El-Masria, Amirria Press, Cairo, Egypt 192: 95.

AOAC (2000). Association of Official Analytical Chemists. Official Methods of Analysis 15th ed. Washington,DC., USA.

Apsaspecialities company (2012). Beneficial effects have been observed from the use of lipidol in all species. Available online at: www.a2m EGYPT.com .

Bancroft, J.D.; A. Stevens and D.R. Turner (1996). Theory and practice of Histological Techniques. $4^{\text {th }}$ ed. New york, Churchill, livingstone.

Baired Parker, A.C. (1962). The occurrence and enumeration of micrococci and staphylococci in becon and on human and pig skin. J. Appl. Bact., 25: 352-361.

Cheeke, P.R.; N. Patton and G.S. Templton (1982). Rabbit Production. $5^{\text {th }}$ Ed. The Intersate Printers and Publishers DanvilleII.

Cheek, P.P. (1987). Rabbit Feeding and Nutrition. Orlando: Academic Press, Inc. Harcourt, Brace, Jovanovich, Publishers.

Conway, E.J. (1958). Micro-diffusion analysis and volumetric error (4 ${ }^{\text {th }}$ Ed.) The McMillan Co., New York.

Difco(1989). Difco Laboratories Incorporated, Difco manual of dehydrated culture media and reagents for the microbiology. Difco Lab., Detroit, Michigan, USA.

Eadie, J.M.; P.N. Hobson and S.O. Mann (1967). A note on somecomparisons between the rumen content of barley fed steers and that of young calves also fed on high concentrate rations. J. Anim. Prod., 9: 247.

Egyptian Ministry of Agriculture (2002). Egyptian Agriculture Economics. Bull.,Centeral Dept. of Agri.,Economics, Cairo, Egypt.

FAO (2000). Statistical Database. (Internet).

Hu,C.H.; A.Y. Zuo; D.G. Wang; H.Y. Pan; W.B. Zheng; Z.C. Qian; and X.T. Zou (2011). Effects of broccoli stems and leaves meal on production performance and egg quality of laying hens. Anim. Feed Sci. \& Tech., 170:117-121.

Huff-Lonergan, E. and S. M. Lonergan (2005). Mechanisms of water holding capacity of meat: The role of postmortem biochemical and structural changes. Meat Sci., 71:194-204.

Ibrahim, Sh. A.M.; H.A.A. Omer; F.A.F. Ali and R.I. El-Kady (2011). Broccoli By-Products as a Partial Replacement of Lucerne Hay in Rabbit Diets Containing Different Levels of Protein. AmericanEurasian J. Agric. \& Environ. Sci., 11: 685-696. 
Juncher, D.; B. Ronn, E. T. Mortensen; P. Henchel; A. Karlsson, L. Skibsted and G. Bertelsen (2001). Effect of pre-slaughter physiological conditions on the oxidative stability of colour and lipid during chill storage of pork. Meat Sci., 58:347-357.

Kim, H.U. and J.M. Goepfert (1971). Enumeration and identification of Bacillus cereus in foods, 1,24hours presumptive test edium. Appl. Microbiol., 22: 581-587.

Lodder, J. (1952). The yeasts. 1st Ed. Pup. Inc., N.Y.

Lohmann-Matthes, M.L.; C. Steinmüller; G. Franke-Ullmann (1994). "Pulmonary macrophages". European Respiratory Journal. 7 (9): 1678-1689.

Manici, L.M.; L. Lazzeri and S. Palmieri (1997). In vitro fungitoxic activity of some glucosinolates and their enzyme derived products toward plant pathogenic fungi. J. of Agric. and Food Chem., 45: 27682773.

Moreno, D.A.; M. Carvajal; C. Lopez-Berenguer and C.G. Viguera (2006). Chemical and biological characterization of nutraceutical compounds of Brocooli, J. of Pharm. and Biomed. Analysis, 15081522.

Postage, J.R. (1969). Viable counts and viability. In: methods in microbiology. Norris, J. R., Robbens, D.W. (eds), vol. 1. Academic Press, London, N.Y.: 611-628.

SAS (2001). SAS User's guide: Statistics, Version $9^{\text {th }}$ Ed. SAS Institute Inc., Cary N.C., USA.

Saman, E.; Q. Muhammad; A. Zainul and M. Ajmal Khan(2016). Secondary metabolites as antinutritional factors in locally used halophytic forage/fodder. Pakistan J. of Botany, 48:629-636.

Steel, R. G. D. and J. H. Torrie (1960). Principles and Procedures of Statistics. (With special Reference to the Biological Sciences.) McGraw-Hill Book Company, New York, Toronto, London,

Steven, W.D.; W.D. Hohenboken; P.R. Cheeke; N.M. Patton and W.H. Kennick (1981). Carcass and meat characteristic of Flemish Giant and New Zealand White purebred and terminal cross rabbits. J. Appl. Rabbit Res., 4: 66.

Tavarez, M. A.; D. D. Boler; K. N. Bess; J. Zhao ; F. Yan; A. C. Dilger; F. K. Mckeith and J. Killefer (2011). Effect of antioxidant inclusion and oil quality on broiler performance, meat quality, and lipid oxidation. Poult. Sci., 90:922-930.

Van Socest, P.J. (1982). Nutritional ecology of ruminant O and B Books. Inc., Corvallis, Oredon. 112: 126-127.

Young Hyun, Yoon Kyung Hyun, Waewaree Boonitam, Yoo Yong Kim, Byoungyun Jung (2016). Effect of Lysophospholipids product (LIPIDOLTM) supplementation on growth performance, nutrient digestibility, blood profiles, and carcass traits in broiler chickens. International Poultry Scientific Forum Georgia World Congress Center, Atlanta, Georgia January 25-26, 2016. 


\title{
أثر إضافة الليبيدول علي الإستفادة من مخلف نبات البروكلي في علانق الأرانب النامية
}

\author{
فاطمة طلعت فرج عبد الغنى ، أيمن رزق حسن حبيب ، أمل مغاورى هيكل و عادل محمد محم سيد أحمد

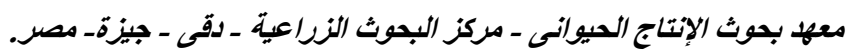

أجري هذا البحث بهدف دراسة تأثير الإحلال الجزئى للعليقة بمخلف نبات البروكلي مع أو بدون إضافة الليبيدول على الأداء الإنتاجى

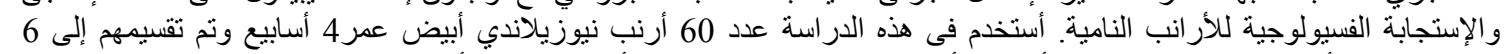

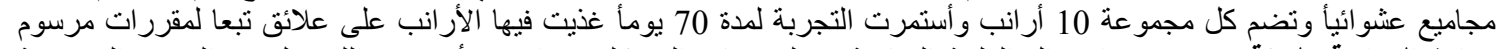

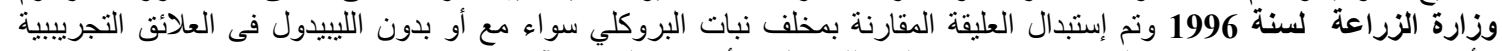

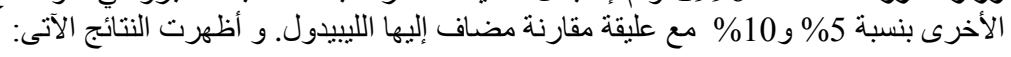

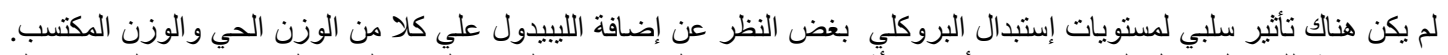

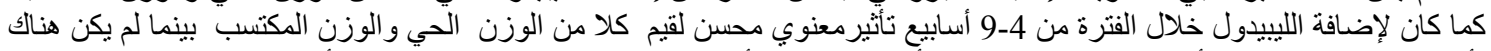

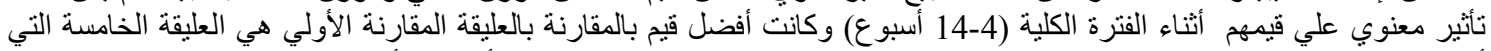

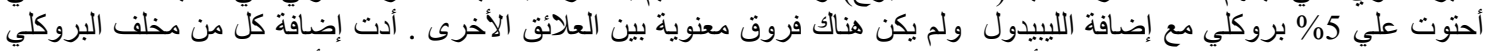

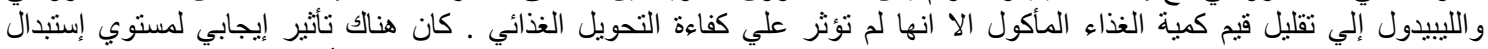

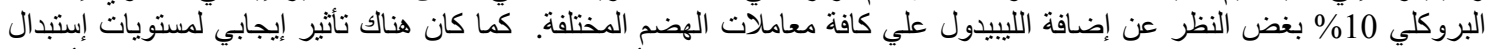

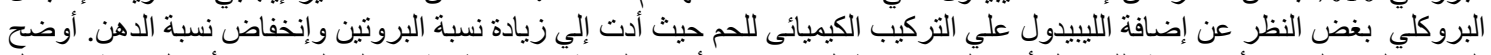

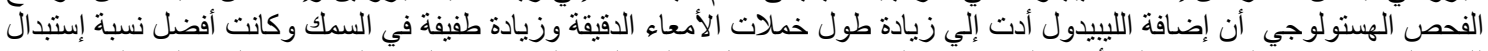

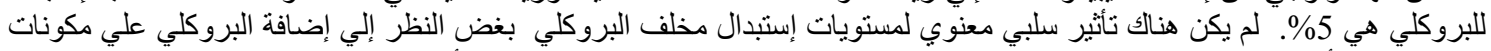

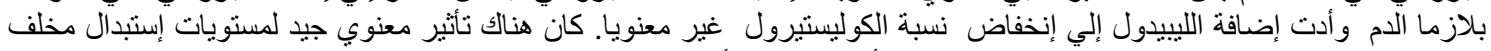

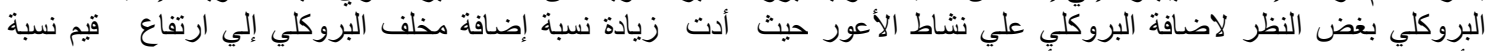

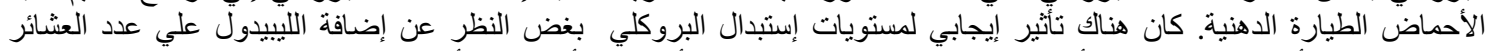

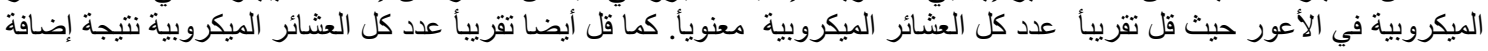
الليبيدول .

كما أوضحت النتائج أنه أزدادت قيم الكفاءة الإقتصادية مع التخذية على العلائق المحتوية على مخلف نبات البروكلي بجميع النسب

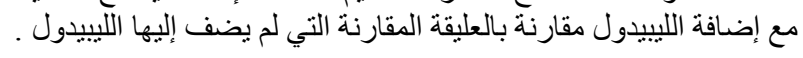

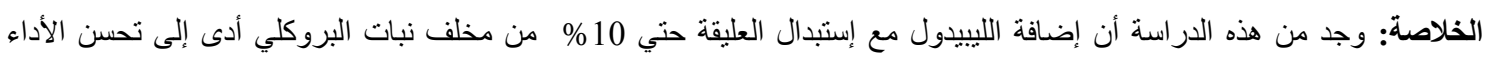

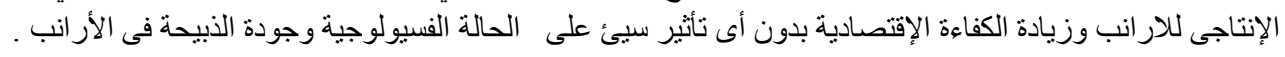

